American Journal of Environmental Sciences 4 (4): 266-275, 2008

ISSN 1553-345X

(C) 2008 Science Publications

\title{
Salinity, Temperature and Turbidity Structure in the Suva Lagoon, Fiji
}

\author{
Awnesh Singh and Than Aung \\ Physics Division, University of the South Pacific, Laucala Campus, Suva, Fiji
}

\begin{abstract}
The city of Suva is home to nearly a quarter of the population of the Fiji thereby placing a lot of anthropogenic pressure on its lagoon. The Suva lagoon (comprising of Suva Harbour and Laucala Bay) has been subject to substantial sediment inputs generated by erosion and human activities. Freshwater input into the lagoon comes predominantly from the Rewa River, the largest fluvial system in the country. The high sedimentary load from the Rewa River, especially during the wet-warm period (November-April), has a strong impact on the lagoon. In addition, there are local sources of pollutant input into the lagoon via the Vatuwaqa River and the Kinoya Sewage Treatment Plant, which discharges effluents into the lagoon and degrades the marine environment. The salinity, temperature and turbidity in the Suva lagoon are some important parameters for water quality which are continuously changing with the seasons and need to be studied because they are efficient indicators of variations in the lagoon and can transform the marine ecosystem. Several field trips were undertaken in the Suva lagoon to collect hydrographical data to study the water properties in the lagoon. Results obtained showed that the salinity near the head of Laucala Bay during the wet-warm period was below $24.8 \mathrm{psu}$ and was $33.7 \mathrm{psu}$ during the dry-cool period (May - October). The temperature range during the wet-warm period was between $28.0-30.5^{\circ} \mathrm{C}$ and between $24.5-25.5^{\circ} \mathrm{C}$ during the dry-cool period. The turbidity was always above 3.0 FTU near the river mouths. The field results show that the variations of CTD measurements are dependent predominantly on the river discharge, while the dominant wind regime is the southeast trade winds.
\end{abstract}

Key words: Fiji, Suva lagoon, water properties, river runoff, wind regime

\section{INTRODUCTION}

Fiji is an island group located in the Pacific Ocean between latitudes $15 \mathrm{~S}-22^{\circ} \mathrm{C} \mathrm{S}$ and longitudes $177^{\circ} \mathrm{C}$ $\mathrm{W}-175^{\circ} \mathrm{C}$ E. All major economic activities are based on its two main islands of which Viti Levu is the largest in size $\left(10388 \mathrm{~km}^{2}\right)$ and population $(>75 \%$ of total population) and hosts the capital city of Suva as shown in Fig. 1. The city of Suva is home to nearly a quarter of the population of $\mathrm{Fiji}^{[1]}$ thereby placing a lot of anthropogenic pressure on its lagoon.

The salinity, temperature and turbidity are some important parameters which are continuously changing with the seasons and need to be studied because they are efficient indicators of variations in the lagoon and can transform the marine ecosystem. Several cruises were conducted to collect necessary data for water quality analysis and the data collected were filtered and analyzed.

Physical geography and bathymetry of the Suva lagoon: The city of Suva is perched on a hilly peninsula between Laucala Bay and Suva Harbour, which

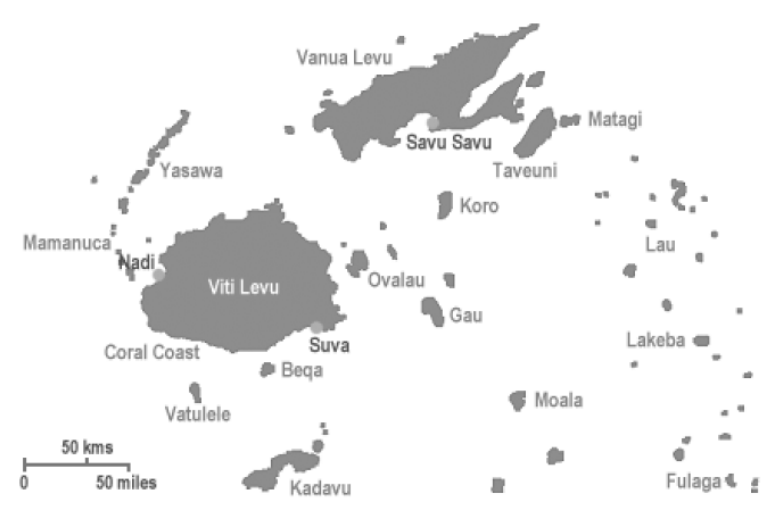

Fig. 1: Map of Fiji ${ }^{[2]}$

together comprise the Suva lagoon in the southeast corner of Viti Levu. The Suva Harbour lays on the west of the lagoon and in between its fringing reefs of Nukusaga and Vunivau lays the Suva Passage as shown in Fig. 2. The Nasese channel links the Suva Harbour and Laucala Bay and is bounded by the Suva Peninsula and the Nawanada Reef. To the east lays Laucala Bay.

Corresponding Author: Awnesh Singh, Physics Division, University of the South Pacific, Laucala Campus, Private Bag, Suva, Fiji 


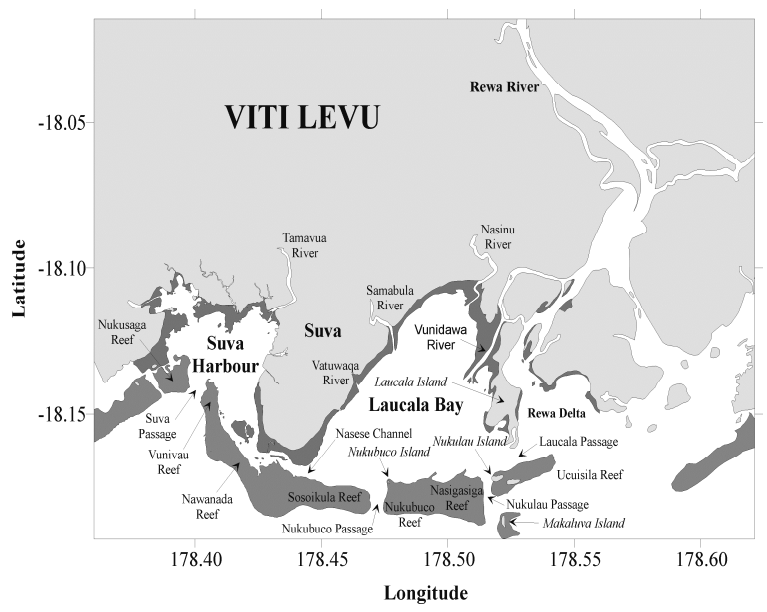

Fig. 2: Map of the Suva lagoon

The Sosoikula and Nukubuco barrier reefs and the Nasigasiga and Ucuisila barrier reefs are broken by the Nukubuco and Nukulau passages respectively. The little islands of Nukubuco and Nukulau form emerged caps on the barrier reef dipping gently into the lagoon, while Makaluva Island is closely exposed to the reef front ${ }^{[3]}$.

The average water depth in Laucala Bay is $9 \mathrm{~m}$ deepening to more than $40 \mathrm{~m}$ in the Nukubuco and Nukulau passages. Laucala Bay is connected to Suva Harbour by the narrow Nasese channel that is $5-10 \mathrm{~m}$ deep. Suva Harbour has an average depth of $15 \mathrm{~m}$ with depths of 80-100 $\mathrm{m}$ in the Suva Passage ${ }^{[4]}$.

Weather over the Suva lagoon: At Suva, the long term (1971-2000) averaged daily maximum and minimum temperatures generally have a direct correlation with the average total monthly rainfall for each month as can be seen in Fig. 3.

The discrepancy during the month of February may be attributed to the lower number of tropical cyclones affecting Fiji during that month as when compared to January and March. Furthermore, tropical cyclones in January and March were much severe and frequent than those in February and since severe tropical cyclones are more likely to bring higher rainfall, the total rainfall for the month is affected. During the cooler months of May to October, the average total monthly rainfall is lower than when compared to the warmer months of November to April.

Tides: At Suva, as in most other places, there are two tides per day (semidiurnal tides). The tidal amplitudes at Suva due to the $\mathrm{M}_{2}, \mathrm{~S}_{2}, \mathrm{~K}_{1}$ and $\mathrm{O}_{1}$ tidal constituents are $0.565 \mathrm{~m}, 0.091 \mathrm{~m}, 0.094 \mathrm{~m}$ and $0.046 \mathrm{~m}$

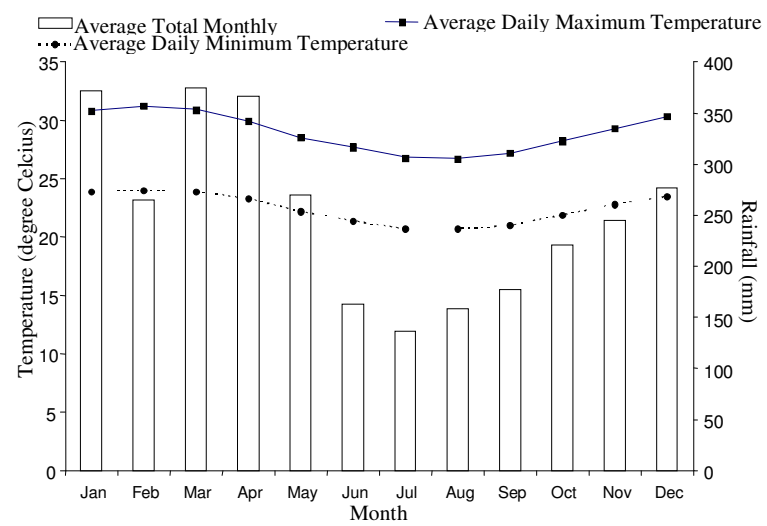

Fig. 3: Long term (1971-2000) average daily maximum and minimum temperatures $\left({ }^{\circ} \mathrm{C}\right)$ and average total monthly rainfall $(\mathrm{mm})$ at Laucala Bay, Suva ${ }^{[5]}$

respectively ${ }^{[6]}$. The area occupied by the water in the lagoon varies with the tide with a mean tidal range of about $1.164 \mathrm{~m}^{[6]}$. At high tide the area is $6.34 \times 10^{7} \mathrm{~m}^{2}$ and $5.57 \times 10^{7} \mathrm{~m}^{2}$ at low tide with the capacity to hold a mean volume of the lagoon of about $7.77 \times 10^{8} \mathrm{~m}^{3[7]}$. Generally, the rise and fall of water level due to tides acts as a major flushing mechanism for a lagoon ${ }^{[8]}$.

River runoff and sedimentation: The Rewa River is the longest river and the largest fluvial system in Fiji. The river is on the island of Viti Levu and originates in Tomanivi (Mount Victoria), the highest peak in Fiji (maximum height above sea-level is $1323 \mathrm{~m}$ ) and flows southeast for $145 \mathrm{~km}$ before splitting up two-thirds on its way downstream into several tributaries. One of these tributaries is the Vunidawa River which channels $15 \%$ of the total discharge of the Rewa River into Laucala Bay while the remainder flows into the Rewa Delta $^{[7]}$. During the dry season, there is a higher percentage of freshwater discharge into the Vunidawa River than into the Rewa Delta. This is because the Rewa Delta is generally closed due to the formation of sand banks and hence a lower percentage of freshwater discharge. However during the wet season, the freshwater discharge into the Rewa Delta increases due to the higher volume of freshwater entering from the Rewa River.

The freshwater input from the Vunidawa River carries a lot of fine sediments and organic particulate matter into the Laucala Bay ${ }^{[9]}$. The Bay area is subject to much sedimentation and has an average depth of 20 meters with a substratum of clayey-silty ooze caused by siliciclastic fluvial input by the Rewa River ${ }^{[10]}$. The Samabula, Nasinu and Vatuwaqa rivers also deposit 
sediments into Laucala Bay and have a combined runoff of over $3 \mathrm{~m}^{3} \mathrm{~s}^{-1}[11]$. Because of the weak currents in the Bay, these sediments are deposited easily and this causes the dirty waters to stay in the Bay for a long time $^{[12]}$. Sediments in the Laucala Bay area are generally very fine while coarser-grained sediments are found close to the barrier reefs ${ }^{[3]}$. Bay muds are about $25-40 m$ thick at Suva Harbour ${ }^{[13]}$.

\section{MATERIALS AND METHODS}

Wind data: The wind data was monitored at the School of Marine Studies at the University of the South Pacific under technical assistance of Research Unit: Characterization and modelling of exchanges in lagoons subject to terrigenous and anthropogenic influences (UR CAMELIA), IRD in Noumea. The wind speed and direction were recorded at regular intervals of $10 \mathrm{~min}$ at a height of $10 \mathrm{~m}$ above mean sea level.

River runoff and rainfall data: The Rewa River discharges freshwater into Laucala Bay through the Vunidawa River (Fig. 2). The Vunidawa River is the major source of variations in salinity, temperature and turbidity in the Suva lagoon. It is therefore important to study the freshwater runoff in order to understand the water properties in the lagoon. However, due to the lack of continuous river discharge data, a relationship between river discharge and rainfall was used to estimate the river discharge from rainfall data obtained from the Fiji Meteorological Service.

Water properties data: The water properties in the Suva lagoon were determined by collecting in situ data using a standard SBE 19 CTD probe and a Niskin bottle. The CTD, which measures conductivity (salinity), temperature and pressure, was fitted with an additional sensor to measure turbidity. The Niskin bottle was used to collect water samples, which were analyzed for suspended sediment concentration (SSC). Among the five cruises that were taken during the wetwarm and dry-cool periods, the data from the best two cruises will be presented in this paper. One cruise each that was undertaken during the wet-warm period and the dry-cool period in 2006 will be discussed.

\section{RESULTS AND DISCUSSION}

Wind regime: The stick plots in Fig. 4 (a- d) show the magnitude and direction of the wind during the wetwarm period (November-April) and the dry-cool period (May-October).
During the dry-cool period, the southeast trade winds are dominant and blow with great regularity over the lagoon as seen in Fig. 4 (c and d). However, during the wet-warm period, the southeast trade winds weaken and the winds generally blow across from the northeast as seen in Fig. 4 ( $a$ and b). During the dry-cool period, there is a high percentage of wind blowing from the southeast (SE) direction, however, during the wet-warm period, the winds are generally blowing from the northeast (NE) direction.

Further analysis of the wind data is done by plotting the percentage wind speed below a benchmark of $2 \mathrm{~m} \mathrm{~s}^{-1}$ for each month during the wet-warm and drycool period and is shown in Fig. 5.

It can be seen from Fig. 5 that the percentage wind speed during the wet-warm period (November to April) is higher than in the dry-cool period (May to October). This implies that stronger winds persist during the drycool period than in the wet-warm period. This can also be observed from the stick plots in Fig. 4 ( $a$ and b), where the wind speed is lower and in Fig. 4 (c and d), where the wind speed is higher. The mean monthly wind speed ranges from $4.4-5.6 \mathrm{~m} \mathrm{~s}^{-1}$ during the drycool period and $3.3-4.5 \mathrm{~m} \mathrm{~s}^{-1}$ during the wet-warm period.

River runoff and rainfall: The combined mean monthly runoffs due to the Nabukaluka, Navolau and Waimanu Rivers, which merge into the Rewa River, show a linear relationship when plotted against the total monthly rainfall at Nausori with a correlation coefficient of $0.87^{[14]}$. Equation (1) shows the relationship between river discharge and rainfall.

$$
R_{d}=0.4393 R_{f}+31.722
$$

where $R_{d}$ is the combined mean monthly river discharge from the Nabukaluka, Navolau and Waimanu Rivers in $\mathrm{m}^{3} \mathrm{~s}^{-1}$ and $R_{\mathrm{f}}$ is the total monthly rainfall at Nausori in $\mathrm{mm}$. The total monthly rainfall taken prior to the cruise date and the mean monthly river discharge calculated using equation (1) for each cruise is shown in Table 1.

Table 1 shows that river discharge during the wetperiod is significantly higher than the amount in the dry-cool period. This implies that the water properties in the lagoon are expected to be influenced more by the

Table 1: Table showing the period, cruise date, total monthly rainfall $\mathrm{R}_{\mathrm{f}} R_{f}$ in mm and mean monthly river discharge $\mathrm{R}_{\mathrm{d}}$ in $\mathrm{m}^{3} \mathrm{~s}^{-1}$

\begin{tabular}{lllll}
\hline Period & Cruise Date & Cruise Name & $\mathrm{R}_{\mathrm{f}}(\mathrm{mm})$ & $\mathrm{R}_{\mathrm{d}}\left(\mathrm{m}^{3} \mathrm{~s}^{-1}\right)$ \\
\hline Wet-Warm & 15-Mar-06 & Cruise 1 & 364.4 & 191.8 \\
Dry-Cool & 06-Sep-06 & Cruise 2 & 110.6 & 80.3 \\
\hline
\end{tabular}


$\mathbf{a}$

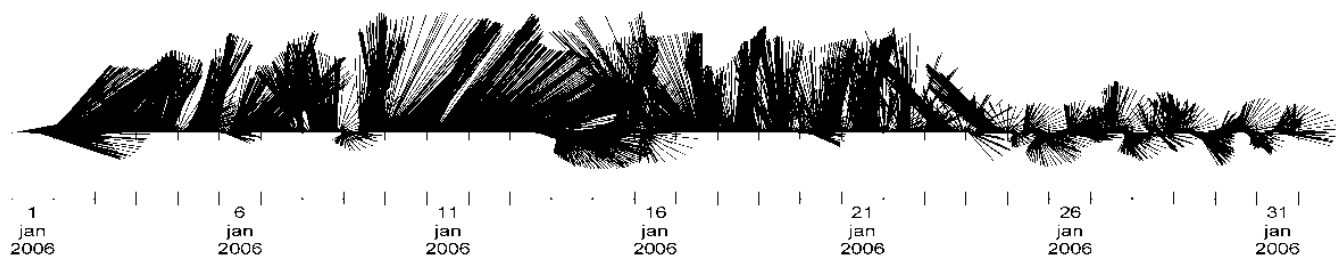

b

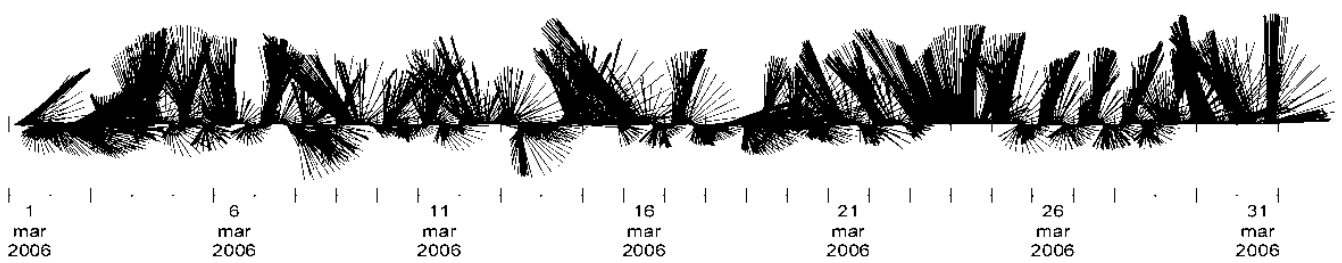

c

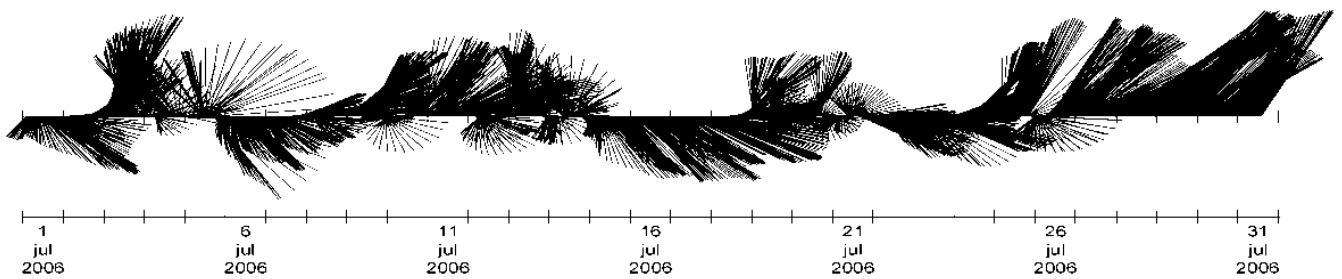

d

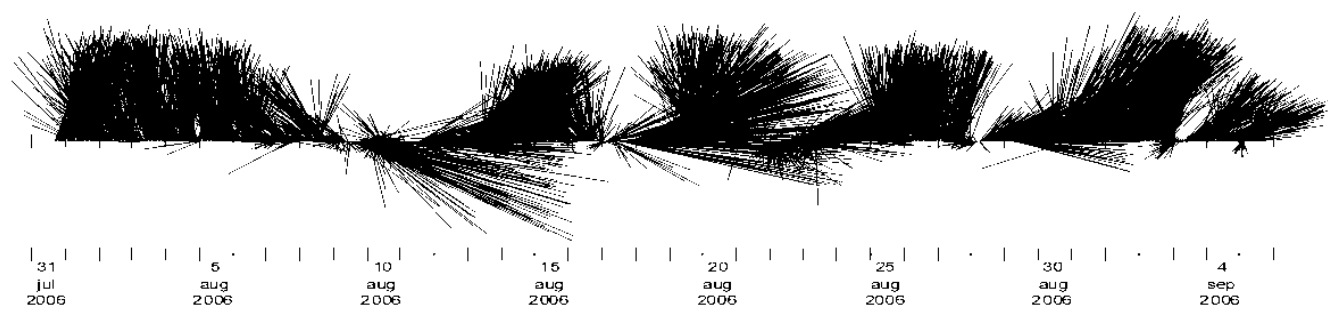

Fig. 4: Two hourly wind stick plots showing magnitude and direction of wind during (a and b) the wet-warm period and (c and d) the dry-cool period for the Suva lagoon. Vertical vectors indicate north-south directional wind and two $h$ filtering is used.

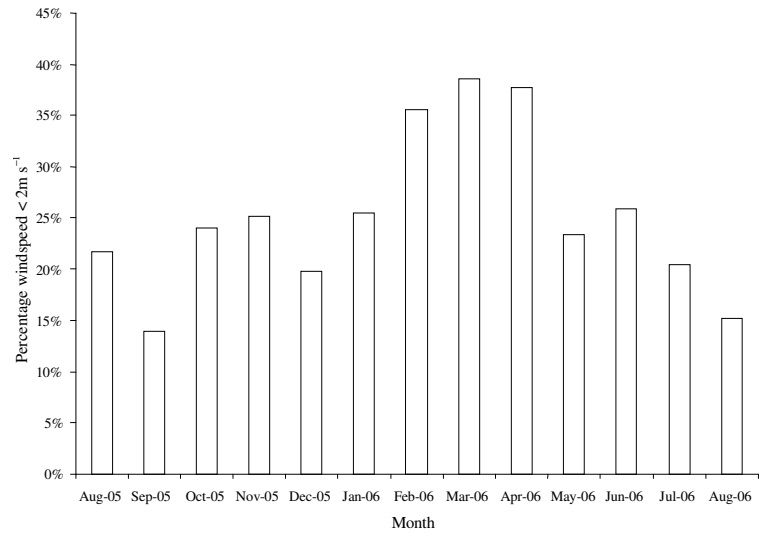

Fig. 5: Percentage wind speed below $2 \mathrm{~m} \mathrm{~s}^{-1}$ for the period between August 2005 and 2006 freshwater discharge during the wet-warm period than during the dry-cool period. Tropical cyclones frequently occur during the wet-warm period and associated heavy rainfall leads to flooding which increases river discharge thereby changing the water properties in the Suva lagoon significantly.

\section{WATER PROPERTIES}

Salinity: The salinity in the Suva lagoon is largely controlled by the freshwater input from the Vunidawa River. During the wet-warm period, there is high rainfall resulting in high freshwater discharge therefore the salinity in the lagoon is expected to be low. The low discharge during the dry-cool period due to low rainfall is expected to affect the lagoon salinity to a lesser extent. 

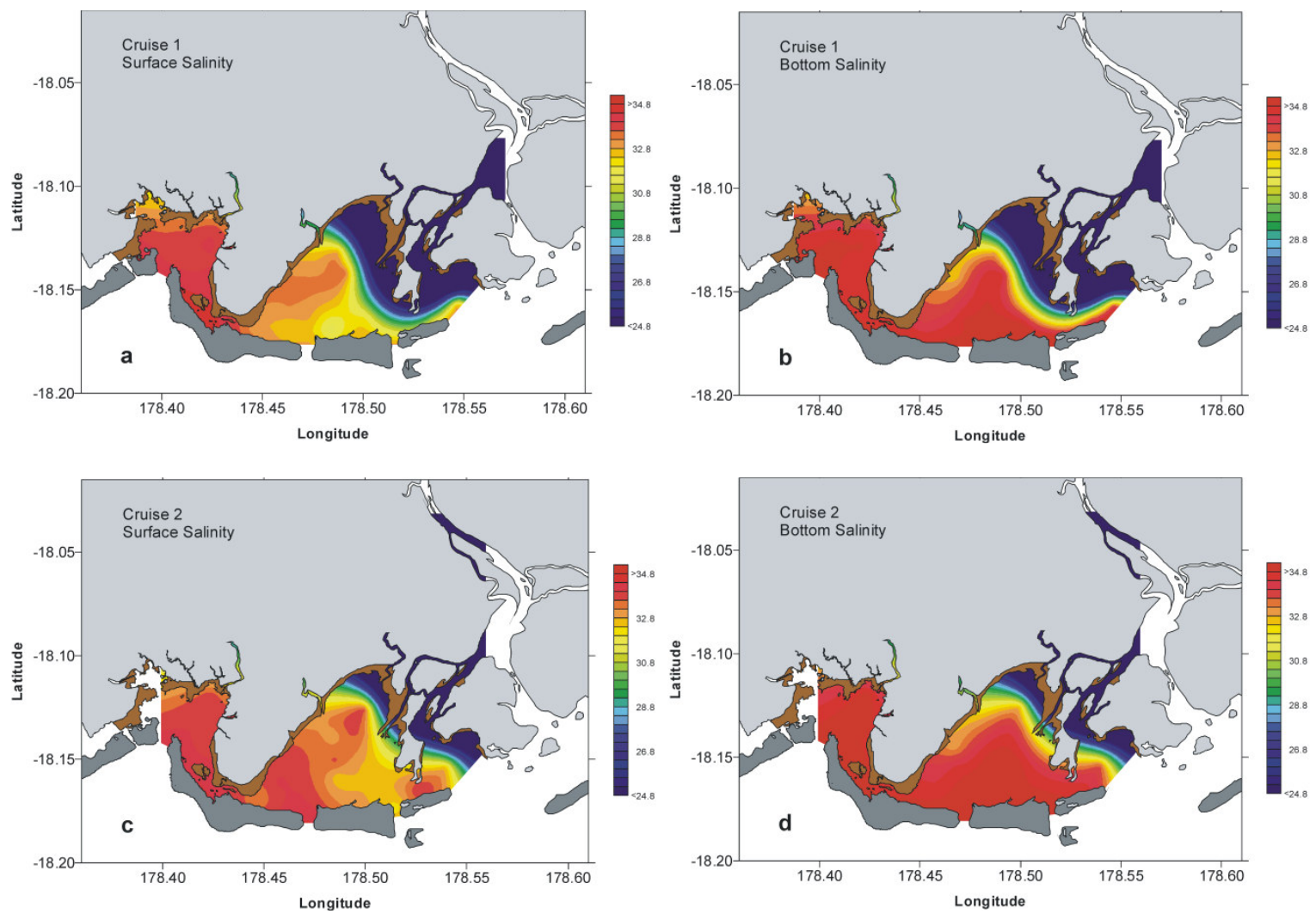

Fig. 6: Horizontal salinity variations (measured in psu) on the surface (left) and bottom (right) in the Suva lagoon during ( $a$ and $b$ ) the wet-warm period and ( $c$ and $d)$ the dry-cool period

The salinity variations in the lagoon were analyzed for the wet-warm and dry-cool period and are plotted in Fig. 6 (a-d).

The low salinity water near the head of Laucala Bay during Cruise 1 is due to the high freshwater discharge from the Vunidawa River entering Laucala Bay. The shallow waters at the head of the Bay kept the surface and bottom salinity below 24.8 psu as can be seen in Fig. 6 a and b. A path of low salinity water on the surface near the head of the Bay was observed to be forming along the shallow Laucala Bay coast. The path is more evident in the bottom layer as seen in Fig. 6b. This path indicates that the freshwater discharged from the Vunidawa River enters the shallow Laucala Bay (average depth of $9 \mathrm{~m}$ ) and begins to flow seaward along the coast. The surface salinity in the Bay was between 31.2-33.3 psu and the bottom salinity ranged from 32.4-34.9 psu indicating freshwater mixing on the surface layer and an influx of seawater through the Nukubuco and Nukulau passages in the bottom layer. The Suva Harbour seems to be isolated from the effects of the freshwater discharge from the Vunidawa River. However, the freshwater discharge from the Tamavua
River affects the surface salinity near the head of the Harbour as seen in Fig. 6a. The surface and bottom salinity in the Suva passage was found to be 34.4 psu and 34.9 psu respectively.

Due to the low freshwater discharge from the Vunidawa River during Cruise 2 (Table 1), the salinity in Laucala Bay was generally found to be higher than during Cruise 1. The surface salinity in Laucala Bay ranged from 33.7 psu near the head of the Bay to 34.5 psu at the Nukubuco passage. The high salinity water entering through the Nukubuco passage at the surface can be seen to move towards Laucala Bay coast in Fig. 6c. This highly saline water extends towards the head of Laucala Bay mixing with the freshwater discharged from the Vunidawa River. As can be seen in Fig. 6c, a spot of high salinity water is found in the middle of the Bay due to the gyre formed by the surface currents. Although the freshwater discharge is low during the dry-cool period, it still influences the salinity in the Bay. The Suva Harbour (average depth of $15 \mathrm{~m}$ ) is unaffected by the freshwater discharge from the Vunidawa River but the freshwater discharge from the Tamavua River does affect the surface salinity (34.0 
psu) as can be seen in Fig. 6c. The bottom salinity in the Harbour shows little horizontal variation and remains uniform at around $35.0 \mathrm{psu}$.

Temperature: The water temperature in the lagoon is expected to be higher in the wet-warm period than in the dry-cool period (refer to Fig. 3). The freshwater input from the Vunidawa River is the major source of temperature variations in the lagoon.

The temperature variations in the lagoon were analyzed for the wet-warm and dry-cool period and are plotted in Fig. 7a-d.

It can be seen from Fig. 7a that the surface temperature in Laucala Bay during Cruise 1 ranges from $30.0^{\circ} \mathrm{C}$ near the head of the Bay to $30.2^{\circ} \mathrm{C}$ in the middle of the Bay and $29.3^{\circ} \mathrm{C}$ at the Nukubuco passage. This is due to the movement of warm surface water away from the head of the Bay and towards the Nukubuco and Nukulau passages. It can also be seen from Fig. 7a that there is an influx of cold seawater from the Nukubuco passage moving towards the middle
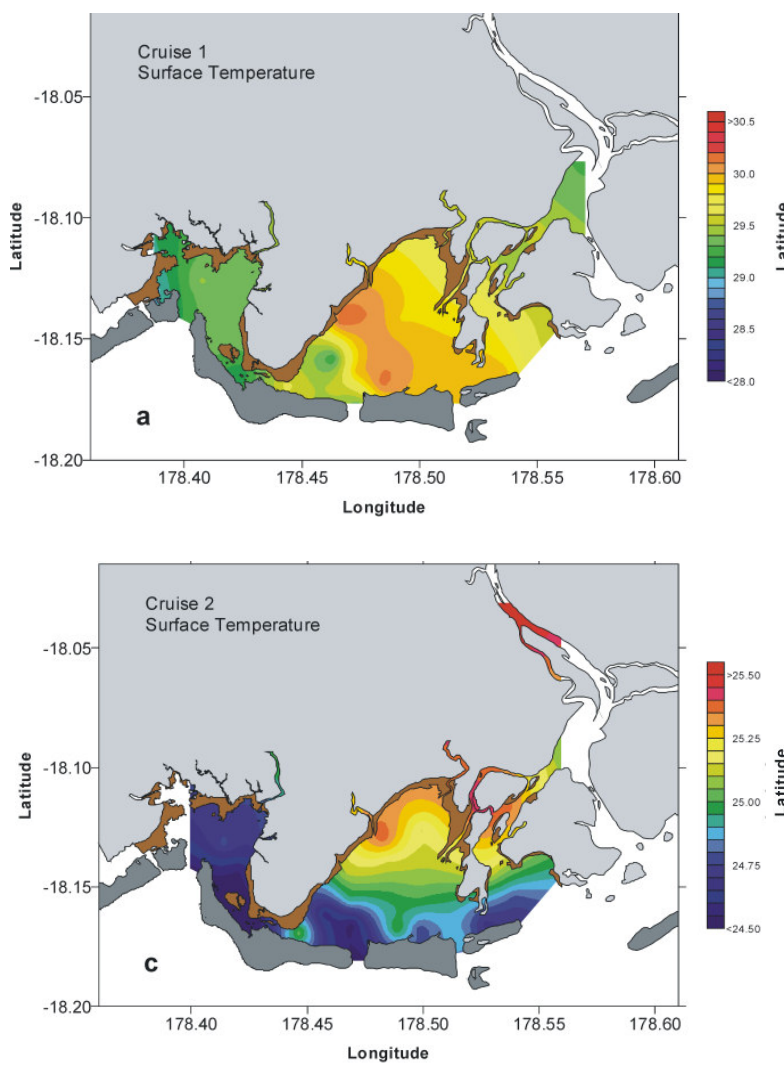

of the Bay. This is more evident in the bottom layer as can be seen in Fig. 7b. Figure 7b also shows cooler water entering through the Nukulau passage and moving toward the head of the Bay. A path of warm freshwater is observed to be moving along Laucala Bay coast towards Nasese channel. The surface and bottom temperatures in Suva Harbour are fairly uniform at around $29.3^{\circ} \mathrm{C}$ and $28.5^{\circ} \mathrm{C}$ respectively showing little or no influence of the effects of the discharge of the Vunidawa River. There are, however, small variations in temperature near the head of the Harbour due to warm water discharge from the Tamavua River.

The surface and bottom temperatures in the Suva lagoon during the dry-cool period were expectedly lower than during the wet-warm period. The surface temperature in Laucala Bay during Cruise 2 ranged from $24.5^{\circ} \mathrm{C}$ near the passages to $25.2^{\circ} \mathrm{C}$ near the head of Laucala Bay as seen in Fig. 7c. Due to the low discharge during the dry-cool period, the warm waters discharged from the Vunidawa River during Cruise 2 remained near the head of the Bay. Cooler waters
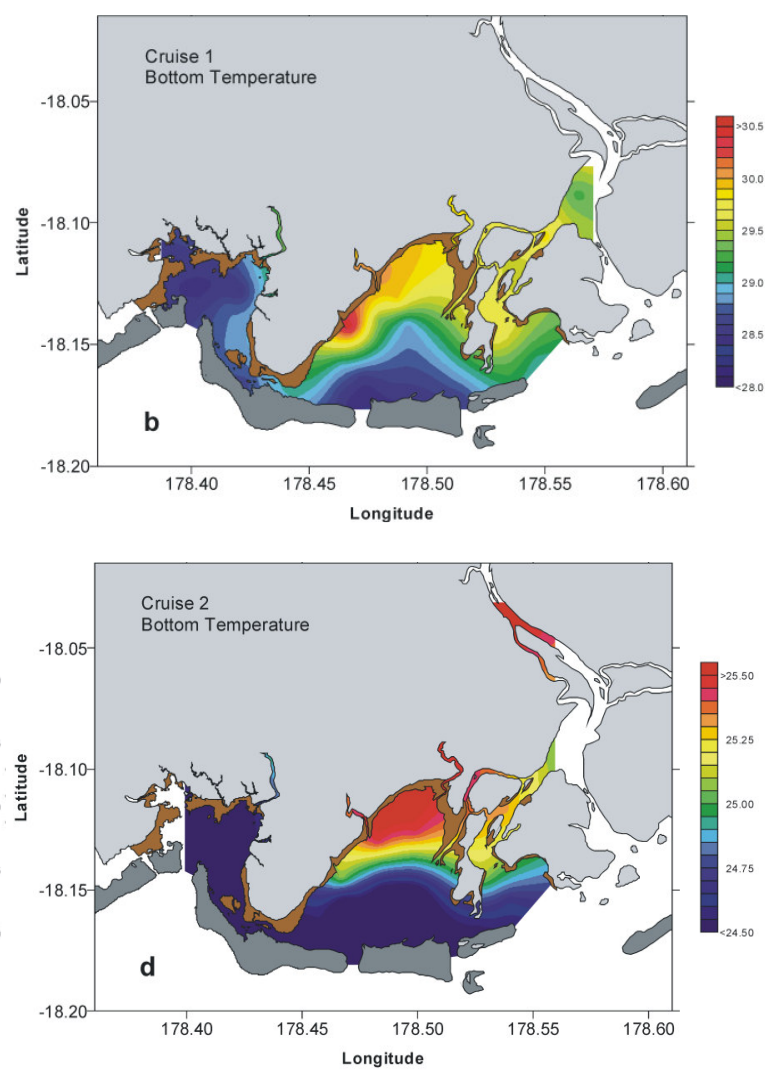

Fig. 7: Horizontal temperature variations (measured in ${ }^{\circ} \mathrm{C}$ ) on the surface (left) and bottom (right) in the Suva lagoon during ( $a$ and $b$ ) the wet-warm period and (c and d) the dry-cool period. 

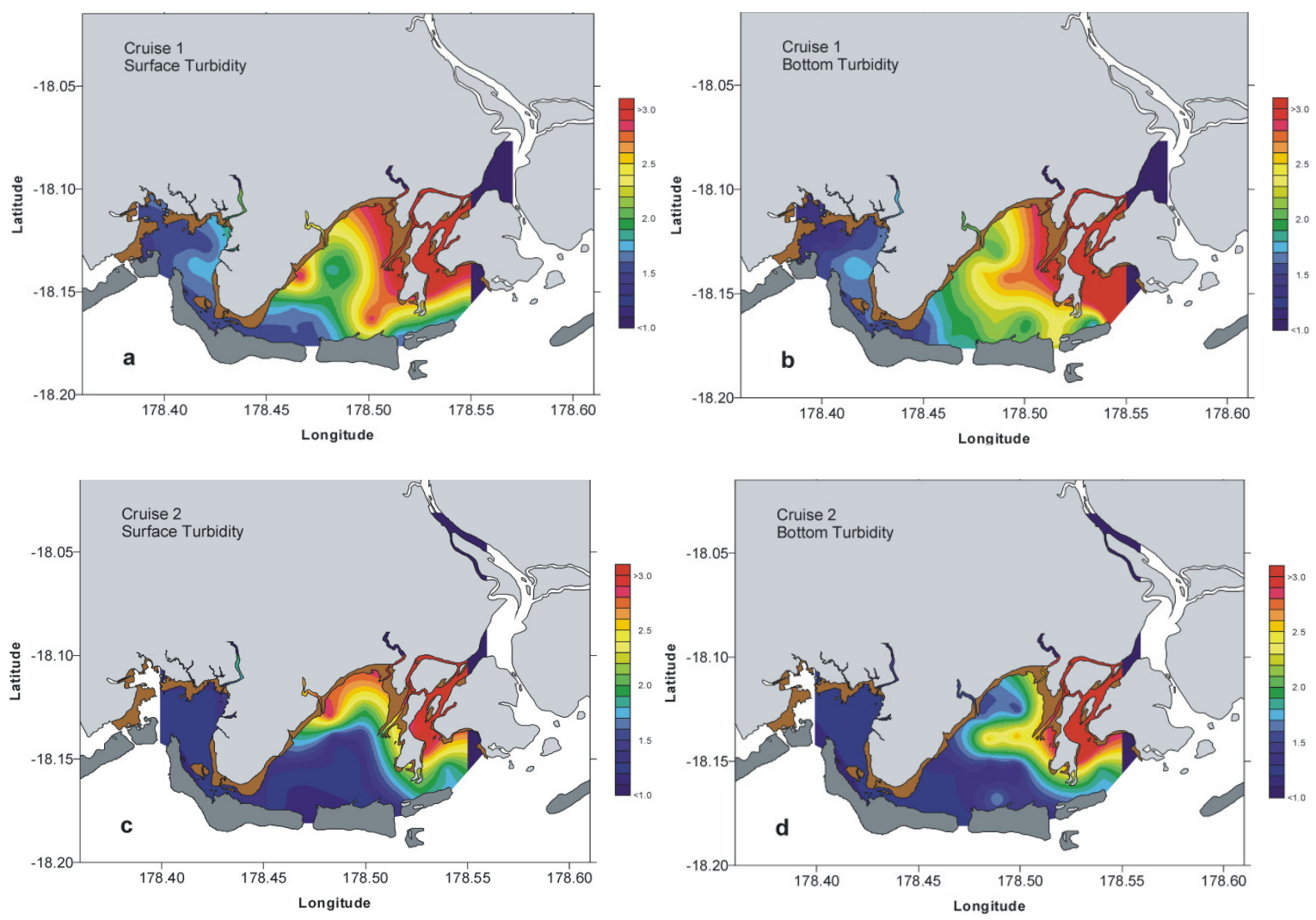

Fig. 8: Horizontal turbidity variations (measured in FTU) on the surface (left) and bottom (right) in the Suva lagoon during ( $a$ and $b$ ) the wet-warm period and ( $c$ and $d)$ the dry-cool period

entering through the Nukubuco passage extended to the middle of the Bay where it mixed with the warm waters discharged from the Vunidawa River. The bottom temperature near the head of the Bay was found to be higher than the surface temperature at $25.5^{\circ} \mathrm{C}$ due to vertical mixing with the warm waters in that area where the depth is generally less than $3 \mathrm{~m}$. A path of warm water was observed to be forming along Laucala Bay coast as can be seen in Fig. 7d. The cool water entering through the Nukubuco and Nukulau passages can be seen to extend towards the middle of the Bay. The surface and bottom temperature at Suva Harbour was uniform at $24.7^{\circ} \mathrm{C}$ and $24.4^{\circ} \mathrm{C}$ respectively.

Turbidity: Turbidity is a measure of water clarity. It is an optical property that expresses the degree to which light is scattered and absorbed by molecules and particles ${ }^{[15]}$. The turbidity in the water column is a result of the presence of soluble colored organic compounds and suspended particulate matter (SPM). These SPM include suspended sediments and organisms. The turbidity in the Suva lagoon is influenced to a large extent by the freshwater input from the Vunidawa River. The turbidity is expected to be high during the wet-warm period when the freshwater discharge is high and low when during the dry-cool period.

Turbidity is measured in Nephelometric Turbidity Units (NTU) or Formazin Turbidity Units (FTU), depending on the method and equipment used. Turbidity measured in NTU uses nephelometric methods that depend on passing specific light of a specific wavelength through the sample. FTU is the unit of measurement when using absorptometric methods (spectrophotometric equipment) and is the one that is used in this project.

The turbidity variations in the lagoon were analyzed for the wet-warm and dry-cool period and are plotted in Fig. 8 (a-d).

Figure 8 ( $a$ and $b$ ) clearly shows that the turbidity in Laucala Bay is always higher than in Suva Harbour. This is because there is higher freshwater discharge into Laucala Bay than into Suva Harbour. The Vunidawa River is the major source of high turbidity in Laucala Bay. It can be seen from Fig. 8 ( $a$ and b) that the 
turbidity in Laucala Bay during Cruise 1 is high at the Vunidawa River mouth. Surface turbidity is 2.0 FTU while the bottom turbidity is $2.8 \mathrm{FTU}$. There is higher turbidity at the bottom due to resuspension of bottom sediments in the water column. Much higher turbidity (3.6 FTU) is observed in the shallow Rewa Delta. There are also discharges form smaller rivers like the Vatuwaqa River and this is evident in Fig. 8a where the surface turbidity at its river mouth is 2.9 FTU and 2.0 FTU at the bottom. The turbidity found at Suva Harbour is less than 1.8 FTU with maxima near the Tamavua river mouth and the west of Nasese channel. The channel is quite narrow and shallow hence there is resuspension of bottom sediments due to the high currents.

Due to lower freshwater discharge during the drycool period, the turbidity in Laucala Bay is less. However, turbid waters (2.9 FTU) were observed on the surface at the mouth of the Samabula River as can be seen in Fig. 8c. The bottom turbidity at the Vunidawa River mouth was found to be higher than the surface turbidity. This is due to resuspension at the bottom stirring up the bottom sediments. Lower turbidity in Laucala Bay is due to lower freshwater discharge during the dry period. The Suva Harbour shows uniform turbidity of 1.2 FTU from the surface to a depth of $30 \mathrm{~m}$.

Suspended sediment concentration (SSC): Turbidity was also measured by determining the mass of SPM in a given volume of sample. The water samples were taken a meter below the sea surface and were filtered using a Whatman nuclepore polycarbonate track-etch membrane filter paper which had a diameter of $47 \mathrm{~mm}$ and porosity, made by laser beams, of $0.4 \mu \mathrm{m}$. The filter paper used in analyzing the water samples for Cruise 1, was an ADVANTEC MFS borosilicate microfiber filter paper. This was not the preferred filter paper but was used as the Whatman filter paper needed was not available at that time. The SSC values for Cruise 2 during the dry-cool period were obtained by using the preferred Whatman filter paper. The SSC was measured in $\mathrm{mg} \mathrm{L}^{-1}$. The water samples were analyzed and the results are plotted in Fig. 9 ( $a$ and b).

The results form Fig. 9a show that high SSC can be seen near the river mouths and along the coastline. Figure 9a shows that high SSC is found at the mouth of the Vatuwaqa River during Cruise 1. It can be said that the Tamavua, Vatuwaqa, Samabula and Vunidawa Rivers all contribute to the increase in SSC in the Suva lagoon. The shallow Laucala Bay coast and the head of Laucala Bay are regions where high SSC can be found. The shallow Rewa Delta is also a high SSC region.
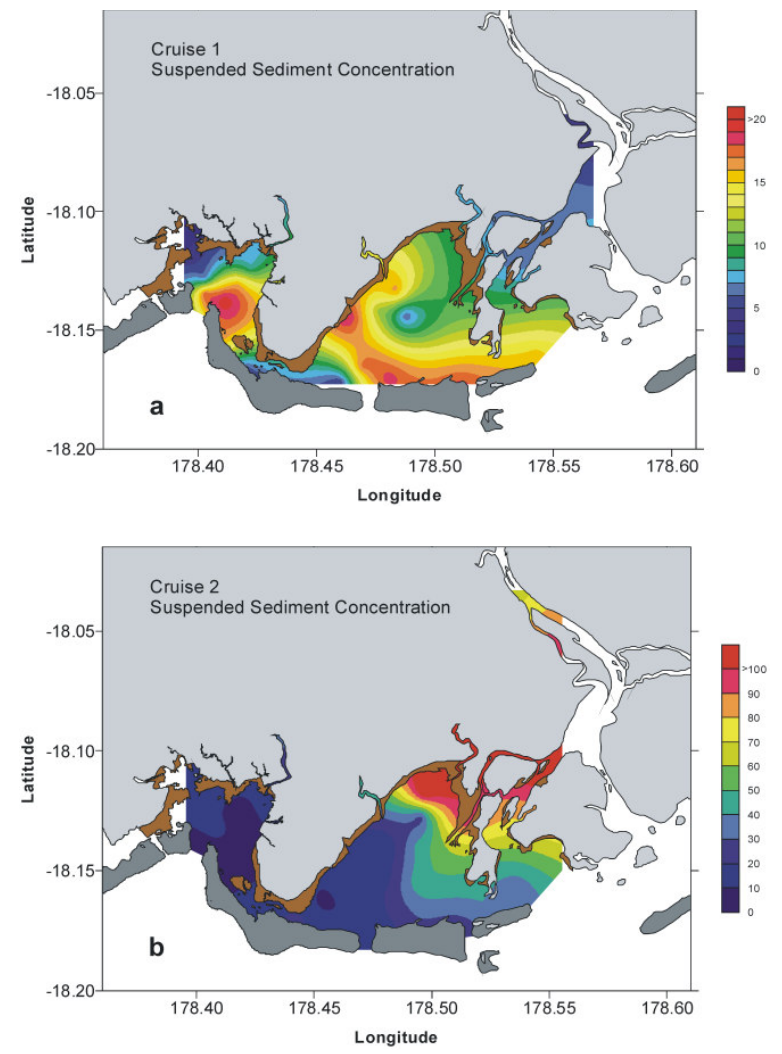

Fig. 9: Suspended sediment concentration (measured in $\mathrm{mg} \mathrm{L}^{-1}$ ) during (a) the wet-warm period and (b) the dry-cool period in the Suva lagoon.

Figure $9 \mathrm{~b}$ shows the relative concentrations at various places in the Suva lagoon. High SSC are found at the head of Laucala Bay and the mouth of the Vunidawa River. The Rewa Delta also shows regions of high SSC. The passages, Nasese channel and Suva Harbour show relatively low SSC.

Turbidity and suspended sediment concentration: If we compare the surface turbidity measured using a CTD probe from Fig. 8a and Fig. 8c with the measured suspended sediment concentration using filtration in Fig. 9a and Fig. 9b respectively, we can see that the best comparison between turbidity and suspended sediment concentration is between Fig. 8c and Fig. 9b. This is due to the better quality of filter paper used in analyzing the results for Cruise 2. A graph of surface turbidity against suspended sediment concentration for Cruise 2 is plotted in Fig. 10.

Figure 10 shows a linear relationship between surface turbidity and suspended sediment concentration with a correlation coefficient of 0.87 . The suspended sediment concentration is related to surface turbidity as given in equation (2). 


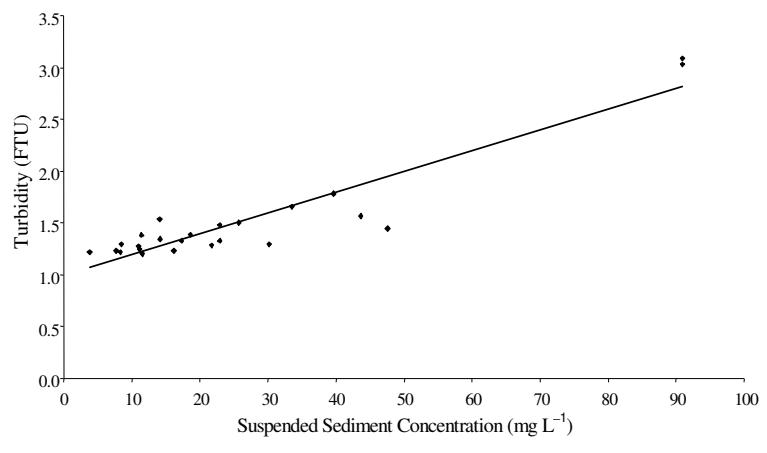

Fig. 10: Relationship between turbidity (FTU) and suspended sediment concentration $\left(\mathrm{mg} \mathrm{L}^{-1}\right)$.

$$
\mathrm{T}_{\mathrm{urb}}=0.0201 \mathrm{SSC}+0.9938
$$

where SSC is the suspended sediment concentration in $\mathrm{mg} \mathrm{L}^{-1}$ and $\mathrm{T}_{\text {urb }}$ is the turbidity in FTU. Looking at equation (2), it can be said that seawater has a turbidity of slightly less than 1 FTU when the suspended sediment concentration is $0 \mathrm{mg} \mathrm{L}{ }^{-1}$. This would mean that seawater is generally clear water but there are other particles which makes the turbidity close to 1 FTU. These particles include organisms in seawater which absorb and reflect light from the turbidity sensor hence increasing the turbidity of seawater.

\section{CONCLUSIONS}

The mean wind direction over the Suva lagoon is generally from the southeast. In addition to the data illustrated in Fig. 4, if we consider the whole year's wind data, we find that the southeast trade winds have a mean annual wind speed of about $6 \mathrm{~m} \mathrm{~s}^{-1}$ and are an important component in the distribution of salinity, temperature and turbidity in the lagoon. River runoff is also a major factor which influences the distribution of these parameters. The high discharge from the Vunidawa River during the wet-warm period is seen to affect the lagoon water properties more than during the dry-cool period.

The southeast trade winds tend to push the freshwater discharged from the Vunidawa River towards the head of Laucala Bay resulting in high temperature and turbidity and low salinity waters being accumulated there. The piled-up water flows back along the Laucala Bay coast and towards Nasese channel. This path of freshwater discharged from the Vunidawa River is evident in Figs. 6 - 8. These figures also show that the influx of seawater through the Nukubuco and Nukulau passages extend up to the middle of the Bay beyond which there is mixing with freshwater at depths of less than $3 \mathrm{~m}$.

The Suva Harbour, unlike Laucala Bay, is protected from the full brunt of the southeast trade winds by the hilly Suva peninsula. The Harbour water properties are more homogenous than in the Bay due to lower freshwater discharge from the Tamavua River (compared to the Vunidawa River) and weaker southeast trade winds. The Harbour is unaffected by the freshwater discharge from the Vunidawa River.

The suspended sediment concentration is a clear indicator of the surface turbidity in the lagoon. A turbidity of slightly less than 1 FTU indicates $0 \mathrm{mg} \mathrm{L}^{-1}$ of suspended sediment concentration. This is comparable to the legal limit of drinking water which is generally less than 1 FTU.

\section{ACKNOWLEDGEMENTS}

We would like to thank UR CAMELIA for the setup of the wind monitoring station, Partnership for Observation of the Global Oceans (POGO) for funding the data collection trips in the Suva lagoon, the technicians from the Physics Division at the University of the South Pacific for assisting in collecting data in the lagoon and the Fiji Hydrology Department and Fiji Meteorological Service for providing the river discharge and rainfall data respectively.

\section{REFERENCES}

1. Viti Levu, 2005. <http://www.factbites.com/topics/Viti-Levu> (date accessed: $22^{\text {nd }}$ November 2005)

2. Map of Fiji, 2006. $<$ http://www.tropicalhoneymoons.com.au/resortsfiji.html> (date accessed: $26^{\text {th }}$ July 2006)

3. N'Yeurt, A.D.R., 2001. Marine algae from the Suva lagoon and reef, Fiji, Australian Systematic Botany, 14: 689-691.

4. Penn, N., 1983. The environmental consequences and management of coral sand dredging in the Suva region, Fiji, $\mathrm{PhD}$ thesis, University of Wales: pp: 267.

5. The Climate of Fiji, 2005. <http://www.met.gov.fj/climate.html> (date accessed: $22^{\text {nd }}$ November 2005)

6. Harmonic Constituents, 2006. $<$ http://tidesandcurrents.noaa.gov/data menu.shtml? unit $=0 \&$ shift $=\&$ format $=$ Apply + Chang e\&stn $=1910000+$ Suva\%2C+Suva + Harbor\%2C++ $\&$ type $=$ Harmonic + Constituents $>$ (date accessed: $26^{\text {th }}$ July 2006) 
7. Campbell, L.E., P.R. Cock and R.A. Corris, 1982. Kinoya sewage treatment plant: Report on receiving water study, report by Commonwealth Department of Transport and Construction and Caldwell Connell Engineers for Public Works Department of the Ministry of Works and Communications, Suva, Fiji: pp: 91.

8. Li, C.W. and J. Gu, 2001. 3D layered-integrated modelling of mass exchange in semi-enclosed water bodies, J. of Hydraulic Res., 39 (4): 403-411.

9. Squires, D.F., 1962. Corals at the mouth of the Rewa River, Viti Levu, Fiji, Nature J., 195: 361-362.

10. Schneider, W., I. Schmelzer and J. Wurtz, 1995. Sedimentological interplay of siliciclastic Rewa River input and organic carbonate production of the Suva barrier reef, Laucala Bay, Fiji, Technical Report, Marine Studies Programme, University of the South Pacific, Suva, Fiji, 95 (4): 26 pp.

11. Naidu, S., W.G.L. Alersberg, J.E. Brodie, V.A. Fuavao, M. Maata, M. Naqasima, P. Whippy and R.J. Morrison, 1991. Water quality studies on selected South Pacific lagoons, UNEP Regional Seas Reports and Studies No. 136 and SPREP Reports and Studies No. 49, South Pacific Environmental Programme, Suva, Fiji: pp: 124.
12. Gendronneau, L., 1985. First dynamic study in Suva Harbour and Laucala Bay: Physical oceanography at the Institute of Marine Resources, Institute of Marine Resources, University of the South Pacific, Suva, Fiji: pp: 4.

13. Shorten, G.G., 1985. Bedrock surface morphology, bathymetry and unconsolidated sediment thickness-Suva Harbour, Ministry of Lands, Energy and Mineral Resources, Mineral Resources Department, Suva, Fiji: pp: 10.

14. Rao, S.A., 2005. Determination of the hydrodynamic circulation of the Suva lagoon, MSc Thesis, University of the South Pacific, Suva, Fiji: pp: 112 .

15. Turbidity, 2006. $<$ http://www.ozestuaries.org/indicators/turbidity.js p> (date accessed: $20^{\text {th }}$ November 2006) 